\section{Peacekeeping operations: from the birth of the United Nations onward}

\section{Lawrence R. Klein}

Tn the historical summary volume, Chronicle of the World, an article appears for 26 June 1945 under the heading "Nations unite to keep peace forever more." From its birth in April 1945 in San Francisco, the United Nations became a reality when representatives from 50 states signed the World Security Charter to establish an international peacekeeping force. The United Nations as we now know it - more than a half century later - still stands and tries to fulfill the promises, hopes, and aspirations of an organization dedicated to the preservation of world peace. Fond memories of excitement linger in my mind about the events of early 1945.

The United Nations still stands and
tries to fulfill the promises, hopes, and
aspirations of an organization
dedicated to the preservation of world
peace.

Attitudes toward the United Nations have changed over this long stretch of time. The U.N. has survived, not as many dreamed in 1945, but as something in place and the only true hope for establishment of a more peaceful world. In this year of 2006, even those nations that would like to sidestep the U.N. in pursuit of their own narrow views of world peace would still like to have the "blessing" of the U.N. From the very beginning of its existence as an established institution with many diverse activities and goals, the central feature remains: the U.N. is the only plausible organizational framework in which to search for peace. Its presence and its objectives cannot be ignored.

Original trouble spots such as Jerusalem (or, for that matter, the entire Holy Land) and Kashmir persist as objectives of U.N. peacekeeping activities. While powerful forces remain intent on struggling in the most gruesome ways to disturb the peace, the prize for finding just settlements of the underlying causes of conflict is still great enough that peacekeeping operations must be kept in place and not turned over to the arrogant forces of open warfare.

The appropriate means for collective security must still be sought, and no ultimate concession can be made to cynical warring factions - not even by hegemonic states who believe that their dominant ways should prevail.

\section{Two extreme approaches}

At the beginning of the United Nations there was overwhelming disgust with the disruptions created by the Axis powers (Germany, Italy, and Japan), and it was felt that the organization could successfully maintain world peace. While the initial peacekeeping operations dealt with the localized disturbances in Jerusalem and Kashmir, for the longer run it appeared that peacekeeping could take place at the world level, coordinated among major powers such as those on the Security Council. This would call for major armed forces, and major financial costs, for which widespread funding was not immediately available after the draining of financial and manpower capabilities by World War II.

Another approach to peacekeeping could derive from the presence of limited involvement by some powers who were able to draw upon general resources or who were so involved that the situation could not be ignored, at any cost. Thus the operations in the Korean War 1950-54 were significant in magnitude, but restricted in area.

Throughout the history of U.N. peacekeeping operations, conflicts escalated and relaxed, and the various states and parties engaged in temporary settlements. But there has never been a decisive attempt by the member states to create a policy for peacekeeping operations. Rather, each conflict is dealt with on a case-by-case basis.

One solution, while not fully tested, is so direct and obvious that it has not been given sufficient, careful thought. The U.N. needs a collective world force with the responsibility and capacity to impose and maintain international peace.

This concept can be seriously investigated from two extreme positions. First, a significant standing army consisting of comprehensive forces from all nations, with sufficient land, sea, and air capabilities to intervene where the accepted international norms of behavior have been violated, to restore order, and to keep the peace. Second, a rapid-reaction force that is much smaller, but always ready for dispatch wherever and whenever needed in order to put down violence and restore peaceful order.

Where might we look for models of the first or second positions? The United States military is instructive. The U.S. has given up compulsory military service while retaining a strong military stance; thus it has a large standing force of professional soldiers. This delivers a good, flexible core that constitutes a large standing military (position 1). The U.S. armed services also have many smaller specialized forces that could be deployed, in units of the size of the French Foreign Legion, to comprise a rapid reaction force (position 2).

\section{U.N. standing armed forces}

When Professor Kanta Marwah and I ten years ago proposed a large U.N. standing army in The Peace Dividend, ${ }^{2}$ our motivating concept was a multinational, standing professional land, air, and sea force. Volunteer forces are not generally accepted as the only institutional way to structure an effective military organization, and while 
our suggestion is not universally adopted either it provides a good starting point.

In The Peace Dividend, we based the statistical analysis on a force of 1 million persons and an annual cost of US\$50 billion. The econometric analysis was based on the international intervention in Yugoslavia: to hold the peace and to bring the composite states together into the European economic environment of the 1990s. Our conclusion was that the size and cost of our "model” U.N. force was reasonable, based on queries of people with major defense responsibilities in the past, and that the outcome would have been fully justified if the standing army could have saved lives and avoided costly conflicts. In fact, we reasoned that the participating countries could have used collective security to lessen the cost of national security. Our solution, of course, remains untried, but if successful it would certainly have been good for the world, for Yugoslavian citizens, and for the fulfillment of the spirit of San Francisco, 1945.

A standing U.N. peacekeeping force of one million persons would have come, in 1996, to about US\$50 billion in annual costs.

If, when the world was confronted by break-up and interstate warring in Yugoslavia, true and complete international security, within the framework of peacekeeping by the United Nations, could have been realized, we might have seen the evolution of a U.N. standing army with a budget that keeps up with inflation and latest developments in military research. Instead, the situation exacerbated the economic breakdown of the U.N. itself.

\section{Rapid reaction force}

Advocates of the more modest alternative, namely the establishment of a U.N.-based rapid reaction force, suggest instead a stepwise approach. Such an approach would start with the deployment of 15,000 people in the field per engagement. With overhead and back-up forces, the total would reach 45,000 persons. This is the force structure imagined by Carl Kaysen and George Rathjens in a recent study of a rapidreaction styled U.N. voluntary force. ${ }^{3}$ In their analysis they indicate that such a force could have made contributions in Yugoslavia, Somalia, Cambodia, Rwanda, and similar areas of localized eruptions of war. Of the four conflicts mentioned, the most susceptible to a successful rapid reaction force would have been Rwanda. The costs of a rapidly placed, properly funded and trained force there could have saved many lives. A peaceful settlement of Yugoslavia after the end of the Cold War would have seemed more suited to an intervention by a U.N. standing army, although some specialized areas could have been well served by a smaller force.

While the large, standing U.N. force considered in The Peace Dividend amounted to approximately US\$50,000 per person per year, Kaysen and Rathjens estimate a partial force, ready to react at once, at about US\$30,000 per person per year.

Both the Klein/Marwah and Kaysen/Rathjens forces and costs are small compared with U.S. military costs (per capita) in the 1991 Gulf War and the continuing wars in Afghanistan and Iraq. While the Kaysen/Rathjens partial force falls far short of a standing army, Kaysen and Rathjens have made a very detailed examination of costs for the rapid reaction force itself, in isolation, and it certainly merits a trial effort. Even if the costs were to be significantly higher, it could be a new step in an important direction. Also, for the price of peace, reasonable people ought to find both approaches - a U.N. standing army and a rapid reaction force - attractive. Senior U.N. diplomats, as well as important officials of earlier U.S. administrations, have looked favorably on the attempts at collective security, and we should have seen enough failures with disastrous consequences to be willing to embark on new ways of dealing with continued unrest in various parts of the world.

A rapid reaction force, with very careful training, would develop capabilities that eventually would enable the U.N. to use it effectively, but nothing like it currently exists. The Associated Press (22 August 2003) reported that a request may be presented to the Security Council to send a U.N. force of 15,000 troops for peacekeeping in then-warring Liberia. This force is large in comparison with the facilities of a rapid reaction force. In future, if such a situation arises again, a highly trained and much smaller rapid reaction force might be used for such a mission. But in this unstable world it would seem more prudent to set our sights higher and create a legion of more than 15,000 persons, to be ready for dispatch where needed, on short notice.

To play its optimal role in the future of peacekeeping operations, the U.N. will have to face up to new demands, beyond those contemplated in 1945. Given the resistance in Iraq that has surprised two major powers (the United States and the United Kingdom), it is plausible that a truly collective effort by the U.N., even at higher costs in people and finance, merits serious consideration in order to secure peaceful lives in the world.

Notes

Lawrence R. Klein is professor of economics at the University of Pennsylvania, Philadelphia, USA. He was awarded the economics Nobel prize in 1980.

1. Mercer, 1996, p. 1016. [Also in Mercer, 1990, p. 645.]

2. Klein and Marwah (1996).

3. Kaysen and Rathjens (2003). [Also see Kaysen and Rathjens, 1995.] 
The Economics of Peace and Security Journal, ISSN 1749-852X

(C) www.epsjournal.org.uk - Vol. 1, No. 2 (2006)

\section{References}

Kaysen, C. and G. Rathjens. 2003. “The Case for a Volunteer UN Military Force.” Daedalus, Vol. 132, No. 1, pp. 91-102.

Kaysen, C. and G. Rathjens. 1995. "Peace Operations by the United Nations: The Case for a Volunteer U.N. Military Force.” Cambridge, MA: American Academy of Arts and Sciences.

Klein, L. and K. Marwah. 1996. "Economic Aspects of Peacekeeping Operations,” pp. 533-553 in N.P. Gleditsch, et al., The Peace Dividend. Amsterdam: Elsevier.

Mercer, D., ed. 1990. Chronicle of the Second World War. London: Longman.

Mercer, D., ed. 1996. Chronicle of the World. New York: DK Publishing. 